\title{
Enforcing Religious Repression in an Age of World Empires: Assessing the Global Reach of the Spanish and Portuguese Inquisitions.
}

\author{
François Soyer \\ Associate Professor \\ (University of Southampton)
}

The Spanish and Portuguese Inquisitions were originally established to put an end to the continued practice of Judaism by Jewish converts to Christianity and their descendants in the Iberian Peninsula. This original purpose was later expanded to include other forms of heresy and the jurisdiction of both Inquisitions was gradually extended beyond the geographical confines of Europe. By the seventeenth century, tribunals of the Spanish and Portuguese Inquisitions were established in the Canary Islands (1507), the Portuguese colony of Goa in India (1560) and the Spanish American colonies of Mexico (1571), Peru (1571) and Cartagena de Indias (1610). The territories that fell within the jurisdiction of these tribunals extended over thousands of square kilometres and in some cases spanned oceans. The Spanish-ruled archipelago of the Philippines, for instance, came under the jurisdiction of the tribunal based in Mexico whilst the Portuguese outpost of Macau in China was placed within the territory watched over by the tribunal of Goa. These extra-European tribunals and their networks of officials (commissioners and familiars) thus transformed the Inquisition into a global institution that claimed jurisdiction over Catholics living in the furthest reaches of the Spanish and Portuguese empires in the Americas, the Atlantic islands, Africa and Asia/Pacific.

This expansion beyond the borders of Europe was also significant because inquisitorial tribunals were at the same time both ecclesiastical tribunals and part of the secular state apparatus. In each Iberian kingdom the supervisory bodies that attempted to coordinate and regulate the actions of provincial tribunals - the Supreme Council of the Spanish Inquisition in Madrid and the General Council of the Portuguese Inquisition in Lisbon - were constituent councils of the Royal Government. It was the Crown, rather than the Papacy, that appointed inquisitor generals in both kingdoms/empires. As such, the Inquisition was the only judicial institution in the Spanish and Portuguese monarchies to operate within a jurisdiction that included both Europe and the overseas empires of both crowns.

The Spanish and Portuguese empires created new trade routes that attracted a highly mobile merchant community, which included many descendants of Jews who had converted to Christianity and were generically known as New Christians or conversos, who were suspected of continuing to embrace Judaism. This mobility of individuals across oceans and territories constituted a problem for an organization whose objective was to police the circulation of religious ideas and particularly to prevent the spread of heretical beliefs from Europe to overseas colonies. This situation was openly acknowledged by contemporaries. As early as 1508, a Castilian royal edict prohibited the emigration to the New World of "the descendants of Jews and Muslims burnt or reconciled [by the Inquisition], up to the fourth generation". Would-be emigrants were supposed to secure permits from the royal agency in Seville that oversaw the implementation of the monopoly on trade between Europe and the Spanish Empire (the Casa de Contratación) by proving the 'purity' of their 
racial/religious pedigree. The repeated re-issue of the decree testifies to the fact that illegal migration and fraud, especially by conversos, were common and this transatlantic movement was greatly facilitated by the dynastic 'union' of Spain and Portugal under Habsburg rule between 1580 and 1640. ${ }^{1}$ In 1619 the highest secular magistrate (procurador general) in the province of La Plata (in modern-day Argentina) argued in favour of the establishment of an inquisitorial tribunal based in Buenos Aires in order to deal with the descendants of Portuguese Jews who had converted to Christianity and were entering Spanish America via La Plata. His main argument was that the Inquisition possessed a network of tribunals covering the empire and was the only court of law "with an administration sufficiently widespread to gather regular intelligence on all the pieces and intrigues [of the Portuguese New Christian communities]. It disposes of the means of intercepting them in their comings and goings". 2

The 'institutional expansion' of the Iberian inquisitions through the foundation of new tribunals in India and the Americas has now been well studied by historians and its historical significance has been noted. A ground breaking history of the 'modern' inquisitions in Italy, Spain, Portugal and the overseas Iberian colonies between 1478 and 1834 has emphasised this point by referring to the history of the Inquisition as a "global history". ${ }^{3}$ Furthermore, the role of the Inquisition in the establishment of a royal and colonial order in the Iberian colonies has likewise been subjected to scrutiny. ${ }^{4}$ Beyond the institutional history of the Inquisition, however, to date little has been written about the effectiveness of the procedures by which the tribunals of the Spanish and Portuguese Inquisitions in Europe and the overseas Iberian colonies sought to communicate, collaborate and coordinate their repressive activity across vast distances.

A recent thought-provoking study by Sylvia Sellers-García has examined the impact that distances and travel conditions had upon administrative or judicial procedures as well as conceptions of 'centre' and 'periphery' in colonial Guatemala but no similar work exists for the intercontinental communication of inquisitorial tribunals. ${ }^{5}$ Modern studies on the activities of individual tribunals of the Spanish and Portuguese Inquisitions in their respective empires have largely focused either on their repressive activity within their jurisdictions or their institutional relations with their respective Supreme Councils in Madrid and Lisbon. Whilst this research has helped to provide the vital building blocks for any analysis of the Inquisition's overall activity, it has not yet provided an answer to two important questions: how effective were the Spanish and Portuguese inquisitions in their attempts to police religious beliefs on an intercontinental scale? Did they develop procedures that enabled them to overcome the constraints placed upon their activity by the vastness of the lands and oceans separating tribunals in Europe, Asia and the Americas and the protracted travel times that these spatial distances created?

\footnotetext{
${ }^{1}$ Ricardo Escobar Quevedo, Inquisición y judaizantes en América española (siglos XVI-XVII) (Bogotá, 2008), 42-4

2 Daviken Studnicki-Gizbert, A Nation upon the Ocean Sea. Portugal's Atlantic Diaspora and the Crisis of the Spanish Empire, 1494-1640 (Oxford, 2007), 159-160.

${ }^{3}$ Francisco Bethencourt, The Inquisition. A Global History, 1478 - 1834 (Cambridge, 2009).

${ }^{4}$ Toby Green, "Policing the Empires: A comparative perspective on the institutional trajectory of the Inquisition in the Portuguese and Spanish overseas territories (sixteenth and seventeenth centuries)", Hispanic Research Journal, 13, 1, (2012), 7-25.

${ }^{5}$ Sylvia Sellers-García, Distance and Documents at the Spanish Empire's Periphery (Palo Alto, 2013).
} 
In its two sections, this article highlights how the Spanish and Portugal inquisitions endeavoured to police religious orthodoxy on a global scale in an era without modern means of communication or personal identification. It examines how the inquisitors struggled to successfully deal with the high mobility of individuals who not only moved within the Spanish and Portuguese empires but also across political boundaries. The first section examines by what means inquisitorial tribunals surmounted the challenge of geographical distance in their attempt to impose orthodoxy throughout the Iberian Empires and ensure that individuals suspected of heresy could not seek to take advantage of the vastness of the Spanish and Portuguese empires to evade justice. Finally, the second section focuses on a single trial from the Indian tribunal of Goa in the early seventeenth century and uses this case-study to illustrate the manner in which the Inquisition was able to overcome the seemingly intractable obstacles of geographical and temporal distance as well as jurisdictional boundaries to successfully prosecute a suspected heretic.

\section{The Inquisitors and the Challenges of Conquering Global Distances}

\section{- Maintaining Communications across Oceans}

In an age without access to any of the rapid means of telecommunication that are presently taken for granted, it could be assumed that the sheer enormity of the geographical distances between Europe and the Americas or India presented an insurmountable obstacle to effective inquisitorial activity. In the Portuguese Empire, the problem of distance was a particularly acute one as only two tribunals - Lisbon in Europe and Goa in India - were responsible for policing the entire Empire between them. The inquisitors of Lisbon held jurisdiction over the Atlantic islands (Madeira, the Azores, Cape Verde, São Tomé e Principe) as well as Brazil and the Atlantic coast of Africa. Their colleagues in Goa were responsible for all the Portuguese colonies in Asia and the coastal areas of East Africa. Inquisitors from Lisbon conducted visitations to the Azores and Madeira (1575-6, 1591-3 and 1618-29), Angola (1596-8) and the Brazilian colonies in Bahia and Pernambuco (1591-5), Bahia (1618-1620) and Grão-Pará (1763-9). There is evidence that their Goan counterparts conducted visitations not only in India but also as far as Malacca and Macau. ${ }^{6}$ Such visitations were inordinately costly and the number of visitations conducted by tribunals in Europe itself declined after the early seventeenth-century and this factor seems to be similarly reflected in their infrequency and decline in Brazil, Africa and Asia. The problem of distance was one that also affected the Spanish Inquisition, as the three tribunals in the Americas were responsible for overseeing religious orthodoxy in districts whose size vastly exceeded those of tribunals in the Iberian Peninsula. Within the vast districts of the extra-European tribunals, even letters sent by inquisitors to their local commissioners could require weeks or months of travel by sea or land before they arrived at their destination. ${ }^{7}$

In spite of these problems of distance and time, letters and documents were nonetheless still sent. A study of the registers of correspondence sent and received by the three European tribunals of the Portuguese Inquisition - Lisbon, Évora and

\footnotetext{
${ }^{6}$ Francisco Bethencourt, The Inquisition. A Global History, 1478-1834 (Cambridge, 2009), 211-245.

${ }^{7}$ Francisco Bethencourt, The Inquisition. A Global History, 237-245.
} 
Coimbra - reveals that they were in relatively frequent contact with the inquisitorial tribunals of the Spanish Americas. By way of illustration, the inquisitors of Lisbon noted that they received and sent letters to Mexico, Peru and the Canaries between 1590 and 1605. Similarly, the register of the correspondence received by the inquisitors of Coimbra between 1587 and 1635 includes letters from Mexico, Lima and Cartagena de Indias in addition to tribunals in neighbouring Spain. ${ }^{8}$ Their letters included requests for information concerning specific individuals or the more speculative sharing of data that might be useful to fellow inquisitors. In 1589, for instance, the tribunal of Mexico City arrested Hernando Rodríguez de Herrera, a Portuguese converso merchant who was a native of the town of Fundão in the Portuguese bishopric of Guarda, for judaizing. They rapidly sent a letter across the Atlantic Ocean to the tribunal of Lisbon in which they included a list of ten individuals residing in Portugal and Spain who had been denounced by Hernando. A surviving copy of this letter, preserved in the registers of the Inquisition of Coimbra, proves that the Lisboan inquisitors sought to coordinate inquisitorial action and circulated the information to the two other tribunals in Portugal. ${ }^{9}$

Transatlantic correspondence between the New and Old worlds was nevertheless greatly hampered by the slowness of transoceanic maritime transport. From the second quarter of the sixteenth century, the Spanish Crown established a system of small mail-packet ships (avisos) to facilitate and accelerate the conveying of important correspondence but this service was irregular and vulnerable to interception. Most mail was probably dependent upon the annual sailings of the ships of the fleet (flota) of galleons that, from the 1560s onwards, travelled between Spain and its American colonies as a convoy for its own protection. Conscious of delays in communication, the Crown attempted to find remedies to this problem in the seventeenth and early eighteenth centuries but its efforts were largely unsuccessful. In 1713, the newly appointed viceroy of Peru was informed that there existed a delay of two to three years in obtaining replies to letters dispatched between Spain and Peru. Communication only significantly improved much later with the creation of a monthly maritime mail service (the correos maritimos) between Havana and Spain in $1764 .^{10}$

In spite of the best efforts of the Spanish Crown to organise an efficient mail system, the sheer distances involved greatly hindered communications. Ships sailing between Spain and the port of Veracruz in Mexico took two to three months. Moreover, correspondence from Spain to Peru (entailing a short overland journey across the Panama isthmus and then by ship to Callao and then Lima) could take a minimum of four, but more usually seven, months. The delay was not just due to travel times but also to the availability of shipping. Letters that missed the sailing of the fleet would have to await the next sailing. The Portuguese inquisitors faced a similar predicament to their Spanish colleagues. The one-way sailing time from Lisbon to Goa, which necessitated lengthy voyages along the African coast and around the Cape of Good Hope, could last from five to seven months. Furthermore,

\footnotetext{
${ }^{8}$ Arquivo Nacional da Torre do Tombo, Lisbon. (henceforth A.N.T.T.), Inquisição de Lisboa, livro 18 and A.N.T.T., Inquisição de Coimbra, livro 70.

${ }^{9}$ A.N.T.T., Inquisição de Coimbra, livro 70 (no foliation in the original).

${ }^{10}$ Xabier Lamikiz, Trade and Trust in the Eighteenth-century Atlantic World: Spanish Merchants and their Overseas Networks (New York, 2010), 95-100.
} 
the sailing of fleets to and from Goa was dictated by the Monsoon season in the Indian Ocean. ${ }^{11}$

To the delays imposed by transoceanic transport were added the dangers of shipwrecks or attacks by corsairs and enemy action at sea which could cut off the flow of news and correspondence between Spain or Portugal and their colonies. References to such mishaps occasionally appear in correspondence between inquisitors and commissioners as late as the final decade of the eighteenth century. By way of illustration, a letter containing important evidence for the prosecution of a errant priest, and dispatched by a commissioner in Brazil to Lisbon in 1796, was lost when the ship carrying it was captured by the French. A second copy, sent in 1797, was apparently also lost in transit as the inquisitors in Lisbon asked the commissioner to repeat his inquiries in $1801 .^{12}$

The slow communications between European and extra-European tribunals caused by geographical constraints were further exacerbated by strict bureaucratic protocol. Letters and requests sent by the tribunals in the Spanish Empire were not directly sent to individual Spanish or Portuguese tribunals but were customarily sent to the Supreme Council of the Spanish Inquisition in Madrid and then forwarded on to the relevant tribunals in Portugal and Spain. Thus, for instance, when the tribunal of Cartagena sought to gather further evidence against Portuguese conversos in its district in the last years of the seventeenth century, it sent a list of names, and physical description to their superiors in Madrid and asked them to forward these on to Portugal. $^{13}$

Even in the vast Pacific area, where the far-flung borders of the Spanish and Portuguese empires and the jurisdictions of the tribunals of Goa and Mexico both met, the movement of fugitives brought into contact their respective commissioners in Macau and Manila. In 1647, seemingly ignoring the fact that Spain and Portugal had been at war since 1640, the commissioner of the Inquisition in the Philippines despatched a familiar to hunt down and arrest two Portuguese fugitives, who were accused of crypto-Judaism and wanted by the tribunal of Mexico. The men were thought to have travelled from Mexico to Makassar in modern-day Indonesia via the Philippines and Macau. When the Portuguese commissioner of Macau was alerted to this situation by the local priest, he conveyed the news and copies of documents received from Makassar back to the tribunal of Goa which, in turn, relayed these on to the General Council of the Portuguese Inquisition in Lisbon. In January 1650, the councillors in Lisbon decided that the men should not be arrested due to insufficient evidence against them and because they were wary of the "difficulties or impediments affecting communications between the inquisitions of Portugal and Spain". ${ }^{14}$

\footnotetext{
${ }^{11}$ On transoceanic sailing see Antonio García-Baquera González, La Carrera de Indias: suma de la contratación y océano de negocios (Seville, 1992) and Artur Teodoro de Matos, Na rota da Índia: estudos de história da expansão portuguesa (Macau, 1994).

${ }^{12}$ James E. Wadsworth, In Defence of the Faith. Joaquim Marques de Araújo. A Comissário in the Age of Inquitorial Decline (Toronto, 2013), 85.

${ }_{13}$ A.N.T.T., Inquisição de Évora, livro 55, fol. 73r (the letter from Madrid was sent on 9 February 1699).

${ }^{14}$ A.N.T.T., Inquisição de Lisboa, processo 13,643.
} 
Inquisitorial documentation does not reveal exactly how letters and bundles of documents travelled between continents. Fortunately, it was customary for inquisitorial notaries to note in the margins of letters the dates when they had been received and when replies were despatched. This act of inquisitorial record keeping offers evidence of the delays caused by slow transport and bureaucratic protocol. By way of illustration, the tribunal of Coimbra in Portugal only responded on 27 January 1614 to a letter dated 12 November 1612 and sent by the tribunal of Lima in Peru seeking background information about an individual suspected of falsely pretending to be an ordained priest. ${ }^{15}$ Similarly, the Portuguese tribunal of Évora only began to address a genealogical enquiry sent from Peru on 11 January 1698 over a year and a half later on 26 August 1699. It sent its reply not directly to Peru but rather to the Supreme Council of the Spanish Inquisition on 23 October 1699 so that it is highly unlikely that the Peruvian Inquisition would have received a reply before the final months of 1700 at the very earliest: over two and a half years after the request had been made. ${ }^{16}$

In the case of trials, the delays in obtaining vital information from other continents imposed severe interruptions upon legal proceedings. The time that letters and documents took to travel between Europe to the Americas or Asia could not be artificially accelerated and could add many years to the normal progress of trials. This was especially the case whenever it was revealed that a prisoner had already been prosecuted and sentenced by a tribunal based in a different continent and it was necessary to obtain confirmation of the nature of these earlier judicial proceedings. Overworked inquisitors and inquisitorial notaries frequently delayed their replies to requests for transcripts of trials from other tribunals, both in Europe and overseas. This problem became evident during the trial of João Vicente, a cobbler arrested by the tribunal of Lima on suspicion of crypto-Judaism, which lasted from 1602 until 1612. A native of Portugal, João Vicente revealed that he and a number of his relatives had been prosecuted and sentenced by the tribunal of Évora in 1582-4. The Peruvian inquisitors decided to verify this information but they were forced to wait for over four years before they received a reply, during which time João Vicente languished in the inquisitorial jail. In the end, however, the information from Portugal confirmed a number of João's claims and although he received a jail sentence in 1612, the documents from Portugal probably saved him from being burnt at the stake. ${ }^{17}$

Just as noteworthy is the case of another Portuguese merchant with Jewish ancestry named Manuel Henriques, who was arrested in Lima in 1635 along with his wife. Manuel Henriques initially lied about having previously been prosecuted by the Inquisition but later admitted a prior prosecution for the same offence by the tribunal of Coimbra in Portugal. Letters sent to Coimbra eventually resulted in a copy of the first trial in Coimbra arriving in Lima in 1641 and his condemnation as a relapsed heretic in 1646. The inability of the impecunious Peruvian tribunal to fund a spectacular auto-de-fé and delays in communications between the tribunal of Lima

\footnotetext{
${ }^{15}$ A.N.T.T., Inquisição de Coimbra, livro 70, no foliation in the original.

${ }^{16}$ A.N.T.T., Inquisição de Évora, livro 55, fol. $100 \mathrm{r}$.

17 The hapless João Vicente was eventually burnt after a third trial, this time by the tribunal of Cartagena de Indias, in 1626. Archivo Histórico Nacional, Madrid, (henceforth A.H.N.), Sección Inquisición, legajo 1,647, document $\mathrm{n}^{\circ} 3$ and A.N.T.T., Inquisição de Évora, processo 7,629. See also Nathan Wachtel, La Foi du Souvenir Labyrinthes Marranes (Paris, 2001), chapter 1 and Ricardo Escobar Quevedo, Inquisición y judaizantes en América, 119-122.
} 
and the Supreme Council of the Inquisition in Madrid delayed his execution by burning at the stake until 1664, circa three decades after his initial arrest. ${ }^{18}$

A prime example of the remarkable length to which the inquisitors were prepared to go in order not to allow political or geographical barriers to adversely affect inquisitorial procedure can be seen in correspondence from the inquisitorial tribunal of Lima in Peru preserved in the archives of the tribunal of Évora. In June 1697 the Peruvian inquisitors were posthumously prosecuting a Portuguese migrant named Alvaro Rodrigues Azeuedo, a native of the town of Portalegre, who had lived in the town of Córdoba del Tucumán in the viceroyalty of Peru (today in Argentina). In order to proceed with the case against the deceased Alvaro, who was accused of having held crypto-Jewish beliefs, the inquisitors required information that could only be obtained from his acquaintances and relatives back in Portugal. Such information would necessitate the public proclamation of an 'Edict of Grace' in Portalegre ordering anyone with information pertinent to the case against Alvaro to present themselves to the Inquisition and divulge their evidence. Since the town of Portalegre lay within the jurisdictional district of the tribunal of Évora, the Lima inquisitors accordingly wrote to the Supreme Council in Madrid, enclosing copies of the 'Edict of Grace' that they wished to have proclaimed in Portalegre. From Madrid, these documents were forwarded to Portugal on 23 July 1699, over two years later. A note made by the inquisitors of Évora indicates that they complied in full with the request of their Peruvian counterparts, sending the 'Edict of Grace' to their commissioner in Portalegre on 26 August 1699 and duly forwarding the testimony collected to the Supreme Council in Madrid on 23 October 1699. ${ }^{19}$

Even more remarkable is the case of Francisco Lopes Lima, a married resident of Recife in the Portuguese colony of Brazil who had run away from his wife. Francisco crossed political borders and became an ordained priest in the town of Córdoba del Tucumán (modern-day Argentina) in the Spanish Empire before returning to Rio de Janeiro in Brazil. Denounced by the wife he had abandoned, Francisco was arrested in 1753 by the ecclesiastical authorities in Rio de Janeiro and then in Recife. The gravity of his offence, impersonating the person of an ordained priest to preach and celebrate the mass, eventually saw him sent across the Atlantic and languish in the jails of the inquisitorial tribunal of Lisbon in September 1757. The nature of his case - involving towns in both the Spanish and Portuguese empires made it inevitable that the inquisitors of Lisbon would seek to obtain details and a confirmation of Francisco's ordination in Córdoba del Tucumán. Extant documents in the trial dossier of Francisco Lopes Lima allow us to reconstruct the slow progression of the flow of information criss-crossing the Atlantic:

- 22 November 1757.

A letter was sent by the Inquisition in Lisbon to the Supreme Council of the Spanish Inquisition in Madrid.

- 16 December 1757.

\footnotetext{
${ }^{18}$ A.H.N., Sección Inquisición, legajo 1,647 , document $n^{\circ} 11$, fol. $141 \mathrm{v}$; for an analysis of these two trials see Irene Silverblatt, Modern Inquisitions. Peru and the Colonial Origins of the Civilized World (Durham N.C., 2004), 40-47 and 59-61.

${ }^{19}$ A.N.T.T., Inquisição de Évora, livro 55, fols. 100r-103v.
} 
The inquisitor general of Spain sent a letter from Madrid to the tribunal of Lima in Peru, forwarding the Portuguese letter.

- 11 May 1759.

The letter from Madrid arrived in Lima (nearly seventeen months later).

- 11 July 1759.

The inquisitors of Lima wrote to their commissioner in Córdoba del Tucumán, asking him to undertake the necessary enquiries. For good measure, they sent two copies of their letter: one directly by land and the other by sea to Chile and then overland.

- 15 September 1760.

A letter with a transcript of the enquiries undertaken by the commissioner arrived in Lima.

- 26 November 1761.

The Supreme Council in Madrid, having received the documents from Peru, forwarded the results on to Lisbon, where they would have arrived in December 1761 or January 1762.

The delays is receiving the necessary evidence from South America - just over four years - eventually exhausted the patience of the Lisbon inquisitors. The trial of the fake priest proceeded despite the absence of documentary evidence of his ordination and concluded in August 1760. Francisco Lopes Lima was publically sentenced and condemned at a public sentencing (auto-de-fé) on 20 September 1761, over two months before the arrival of the evidence from South America. ${ }^{20}$

- Establishing Identities in an Era of Global Mobility:

The role of the inquisitorial commissioners in facilitating the operations of inquisitorial tribunals was crucial in Europe but it became absolutely vital across oceans and the vast territories of the Americas and Asia. They allowed inquisitors to retrieve information from records scattered both throughout their districts as well as in other continents. Yet, despite their importance, the study of the inquisitorial commissioners scattered throughout the Americas and Asia remains patchy and focuses on establishing the extent of these networks in given districts rather than on the biographies and specific modus operandi of individual commissioners.

In the case of the Iberian overseas empires, however, the work of various historians is slowly bringing the role of the commissioners out of obscurity. Particularly noteworthy are recent studies by James Wadsworth and Miguel Lourenço of the inquisitorial commissioners operating in Pernambuco (Brazil) and Macau

\footnotetext{
${ }^{20}$ A.N.T.T., Inquisição de Lisboa, processo 8,675. I am extremely grateful to Gustavo Augusto Mendonça dos Santos for bringing this case to my attention and allowing me to read his wonderful M.A. thesis "Transgressão e cotidiano: a vida dos clérigos do hábito de São Pedro nas freguesias do açúcar em Pernambuco na segunda metade do século XVIII (1750-1800)", Universidade Federal Rural de Pernambuco, Recife, 2013.
} 
respectively. ${ }^{21}$ The network of commissioners of the tribunal of Goa in India was particularly widely distributed and dependent upon a network of Portuguese churchmen scattered across Asia. As early as 1566, less than five years after the establishment of the Goan tribunal, the Portuguese viceroy in India ordered the captains of Portuguese vessels to accept any prisoners entrusted to them by the bishops in the Portuguese territories of Mallaca (modern-day Malaysia) or Cochim (southern India) or the ecclesiastical officials and vicars in "Hormuz, Mozambique or any other place of their archbishopric". Motivated by the size of their jurisdiction, the Goan inquisitors granted their commissioners far more powers than those enjoyed by their European counterparts, including the power to absolve and prosecute defendants. The situation was not, however, to the taste of the General Council in Lisbon which attempted to restrict such measures during the seventeenth century. ${ }^{22}$ Recent research has proven that even in Macau, that most distant Chinese trading outpost of the Portuguese empire and officially within the jurisdiction of the Indian tribunal of Goa, the Inquisition was certainly not inactive. The inquisitorial commissioner in Macau was instrumental in facilitating at least seventeen trials of suspects from Macau that were conducted in Goa between 1561 and $1623{ }^{23}$

The need to verify the identity of suspected heretics or delinquents and the veracity of their claims became one of the principle objectives of correspondence between all tribunals of the Inquisition, either within Europe or outside of it. The inexistence of compulsory identity papers and the lack of any fixed naming pattern enormously complicated the task of tracking or positively identifying individuals and was a problem faced by judicial authorities all over early modern Europe but perhaps even more by the Iberian Inquisitions. ${ }^{24}$ Obtaining such information was not only critical to mounting successful prosecutions but also to completing the genealogical investigations establishing the limpieza de sangre (purity of blood, free from Jewish or Muslim ancestry) of individuals seeking to become lay officials of the Inquisition. Individuals used surnames that could be patronymic (such as Juan Fernandez) or toponymic (such as Juan de Trujillo) and in many cases were often known through rather crude sobriquets referring to distinctive physical characteristics such as "fatty" (el gordo) or "the blonde" (la rubia). Consequently, individuals or members of a family could seek to conceal their identity and origins with relative ease when relocating from one continent to another. As the cases of Francisco Lopes Lima (described above) and Mateus Salomão (examined in the second section of this work) demonstrate, the vast distances separating the Old and New Worlds and their inquisitorial tribunals compounded these problems.

\footnotetext{
${ }^{21}$ See James E. Wadsworth, Agents of Orthodoxy. Honor, Status, and the Inquisition in Colonial Pernambuco, Brazil (Toronto, 2007) and In Defence of the Faith. Joaquim Marques de Araújo. A Comissário in the Age of Inquisitorial Decline (Montreal, 2013); M. Lourenço Miguel Rodrigues Lourenço, "O Comissariado do Santo Ofício em Macau (c.1582-c.1644): A Cidade do Nome de Deus na China e a articulação da periferia no distrito da Inquisição de Goa", University of Lisbon (M.A. thesis), 2007.

${ }^{22}$ Miguel Rodrigues Lourenço, Macau e a Inquisição nos séculos XVI e XVII - Documentos (Lisbon, 2012), I, 23-6; Bruno Feitler, "A delegação de poderes inquisitoriais: o exemplo de Goa através da documentação da Biblioteca Nacional do Rio de Janeiro”, Tempo, 24 (2008), 127-148.

${ }^{23}$ Miguel Rodrigues Lourenço, "Macau, porto seguro para os cristãos-novos? Problemas e métodos sobre a periferia da Inquisição de Goa", Cadernos de Estudos Sefarditas, 10-11 (2011), 451-500.

${ }^{24}$ For a Europe-wide perspective see Miriam Eliav-Feldon, Renaissance Impostors and Proofs of Identity (London, 2012).
} 
Beyond the archives of other inquisitorial tribunals, the principal font of information to which inquisitors seeking to establish an individual's identity and past deeds frequently had recourse were ecclesiastical registers, such as those recording ordinations and baptisms. In the case of individuals who had crossed oceans, such searches necessitated contacting tribunals overseas and requesting them to undertake the investigations through their commissioners. By way of illustration, on 20 December 1700 the inquisitors of Llerena, acting on behalf of their colleagues in Peru, petitioned their Portuguese counterparts in Évora to assist them in conducting an investigation into the racial purity of Antonio Lobo de Melo, who wished to become a familiar of the Inquisition of Peru. The inquisitors were keen to verify the exact identity of the applicant's paternal grandmother and asked their Portuguese colleagues to search through the baptismal registers in the town of Villa Viçiosa between 1616 and 1624 to verify her limpieza. The Portuguese inquisitors fulfilled the request but not rapidly enough to prevent their Spanish counterparts sending them a reminder the following year. ${ }^{25}$

In order to establish the guilt of a forty-one-year-old native of Portugal accused of two bigamous marriages (triplici matrimonio), the Peruvian inquisitors wrote to the Portuguese inquisitors of Évora in April 1718. They knew that the individual concerned, who had voluntarily come forward to denounce himself for reasons that are not explained in the letter, had changed his (Hispanicised) Portuguese name from D. Andrés de Mendoza, y Villavicencio to Andrés Díaz Súarez Nuñez. He had been born in a village in the district of the town of Tavira in the Algarve and his first marriage had been to a Portuguese woman twenty-six years before. The Peruvian inquisitors provided a large quantity of genealogical details and other information that they believed would help their Lusitanian counterparts verify this claim and asked for an authenticated copy of the result of the enquiries to be returned to them. ${ }^{26}$

The issue of extraditions of prisoners between the Americas and Europe was discussed as soon as the tribunals of Mexico and Peru were established in 1571. The Supreme Council in Madrid noted that many fugitives fled to the Americas and decided that names of fugitives would be forwarded to Mexico and Peru "so that the inquisitors who reside in the Indies should make the relevant inquiries". If the fugitives were found, they were either to be handed over to the tribunal, presumably in Europe, where a case against the fugitive was pending or, alternatively "the most convenient course of action should be taken". ${ }^{27}$ In practice, however, the transfer of information - such as lists of wanted fugitives (complete with accurate physical descriptions, biographical information and known pseudonyms) or documents specifically requested by one tribunal from another - proved to be a more practical solution than the extradition of prisoners. Whilst there exists documentary evidence of a number of extraditions of prisoners, overwhelmingly conversos, between the tribunals of the two Inquisitions in Europe, there no evidence of prisoners extradited from Spain's American colonies to Europe or vice versa. ${ }^{28}$ It was only in the case of

\footnotetext{
${ }^{25}$ A.N.T.T., Inquisição de Évora, livro 55, fols. $174 \mathrm{r}-175 \mathrm{r}$ and $222 \mathrm{r}-224 \mathrm{v}$.

${ }^{26}$ A.N.T.T., Inquisição de Lisboa, livro 26, fols. 2r-2v.

${ }^{27}$ A.H.N., Sección Inquisición, libro 326, fols. 255v-256r.

${ }^{28}$ On extraditions between inquisitorial tribunals in Europe see Ana Isabel López-Salazar Codes, "La relación entre las Inquisiciones de España y Portugal en los siglos XVI y XVII: objetivos, estrategias y tensiones", Espacio Tiempo y Forma. Serie IV, Historia Moderna, 25 (2012), pp. 223-252 which corrects some misconceptions in my earlier work F. Soyer, "The extradition treaties of the Spanish and
} 
the Portuguese Inquisition that transoceanic transfers of prisoners regularly took place and then it was generally not between tribunals but within the jurisdictional area of the tribunal of Lisbon: from Brazil to Portugal. In this particular case, the transfer of prisoners to Europe was unavoidable if their trials were to be successfully conducted. $^{29}$

\section{A Case Study in the Inquisition's Global Reach: The Trial of Mateus Salomão (1610-1614)}

The ability of the Inquisition to overcome the many obstacles presented by trials involving suspects who had travelled between continents is remarkably well illustrated by trial dossier number 5,037 in the archives of the Inquisition of Lisbon. Mateus Salomão, a military engineer arrested in September 1610 by the inquisitorial tribunal operating in Goa in India. Mateus Salomão travelled from Europe to Goa in 1602 on the same ship carrying the entourage of the Persian ambassador returning to Persia after a diplomatic visit to Europe. He was sent to India not just as an escort to the Shah's ambassador but also to bolster the defences of Goa. ${ }^{30}$

Mateus Salomão's detention was the result of testimony collected by the inquisitors during the trial of an immigrant from the Holy Roman Empire named Leonardo Lobo, a German suspected of harbouring protestant ('Lutheran') beliefs. ${ }^{31}$ After his arrest in October 1609, Leonardo Lobo was subjected to a series of interrogations in which he implicated a number of his friends, including Mateus Salamão. Lobo claimed to recall conversations with Mateus Salamão in which the latter expressed sympathy for the beliefs of Lutherans, criticised the adoration of sacred images as "idol worship" and accused the Catholic clergy of using unspecified "herbs" to control the populace. Worse still, regarding the Inquisition, Salamão had allegedly accused the inquisitors of also using herbs with peculiar properties in order to gain knowledge of "all the things and secrets that accused persons have committed or uttered" and claimed that God was displeased "by the sight of so many tribunals of the Holy Office of the Inquisition in these realms of Castile and Portugal and the harsh punishments they meted out". Finally, he had boasted of possessing a prohibited book that had once been confiscated by the Inquisition in Italy but later returned to him. When the inquisition asked Lobo to provide information regarding the identity of Mateus Salamão, Leonardo Lobo stated that Mateus Salomão claimed that he was the son of a Basque man and gave his physical description as "forty-five years of age more or less, with a thick black beard, tall and thin, and very laconic in his speech", 32

Unsurprisingly, the inquisitorial prosecutor in Goa submitted a petition on 25 August 1610 requesting that Mateus Salomão should immediately be arrested and

\footnotetext{
Portuguese Inquisitions (1500-1700)", Estudios de Historia de España, 10 (2008), Universidad Católica Argentina (Buenos Aires), 201-238.

${ }^{29}$ On the Inquisition's anti-converso activity in Brazil see Bruno Feitler, Inquisition, juifs et nouveauxchrétiens au Brésil. Le Nordeste XVII e et XVIII ${ }^{e}$ siècles (Leuven, 2003),

${ }^{30}$ This was the embassy of Husein Ali Beg, who travelled to Europe through Russia and the Arctic port Arkhangelsk 1599 before returning to Persia via Goa on a Portuguese ship in 1602. See Luis Gil Fernández, El Imperio Luso-Español y la Persia Safávida, Vol. I (1582-1605) (Madrid, 2006), 79-142.

${ }^{31}$ The inquisitors noted that Leonardo Lobo, presumably Leonard Wolff in his native German, was a native of the town of Açengram. Unfortunately, the Portuguese corruption of the original German name renders it impossible to positively identify the town concerned.

${ }^{32}$ A.N.T.T., Inquisição de Lisboa, processo $\mathrm{n}^{\circ} 5,037$, fols. $10 \mathrm{v}-12 \mathrm{v}$.
} 
placed on trial. The following day the inquisitors unanimously agreed that the arrest should take place in view of the fact that the confession appeared to be offered "without malice" in their eyes and that both the men concerned were foreigners. An arrest warrant was duly issued on 7 September and Mateus Salomão was detained the same day.

In accordance with inquisitorial procedure, the inquisitors asked Mateus Salomão to provide a series of biographical details during his first interrogation on 9 September 1610. The prisoner confirmed that his name was Mateus Salomão and that he was an "Old Christian" untainted by Jewish or Muslim ancestry, aged a little over forty. He maintained that he was a native of the Basque country but that he had been raised as a young child in Germany. He had been married in Madrid, where he had left his two sons, but was currently a widower. Furthermore, he described himself as a military "engineer" (engenheiro) and servant of the King of Spain and Portugal. ${ }^{33}$

Mateus Salomão appears to have been unnerved by his arrest and immediately confessed that he had already been arrested by the Inquisition once before although not in India or even Portugal. His first arrest had been on the Spanish-ruled island of Sicily. ${ }^{34}$ The prisoner straightforwardly admitted to the inquisitors that this first arrest took place four years previously in Palermo, in the Kingdom of Sicily and offered a somewhat convoluted and confusing account of the causes of his arrest. According to Salomão, his troubles had begun with his imprisonment in a secular jail following a serious incident, the circumstances of which not explained, when he fired a musket at the son of the Duke of Feria, the Spanish viceroy in Sicily. The prisoner claimed that this event incited two Sicilian clerics to falsely denounce him to the local inquisitorial tribunal for possessing a book of necromancy "in the Turkish language". Moreover, he had been accused of expressing the belief in universal salvation: that good Muslims could save their souls in their own faith and without converting to Christianity. Salomão strenuously denied this claim and was insistent that this first trial had not resulted in a conviction but rather in his complete exoneration. Moved by his conscience, one of the Sicilian clerics had voluntarily confessed to committing perjury and the other had accordingly been condemned as a perjurer and sentenced to serve in the King's galleys. The suspicious book was returned to him after it was examined by the Sicilian inquisitors and revealed to be an innocent work in German on the art of navigation. ${ }^{35}$

Two months elapsed before the Goan inquisitors decided to conduct a final interrogation of Mateus Salomão on 20 November 1610. This time the prisoner reiterated his claim not to have committed any crimes that concerned the Holy Office and continued to seek to identify, and discredit, the source of any testimony against him. He now added another dimension to the case by informing the inquisitors of a second run-in with the Inquisition, this time with the inquisitorial tribunal of Valladolid in Spain. Mateus Salomão confessed that, nine years prior to his arrest in Goa, his now-deceased Spanish wife had laid false charges against him to the Inquisition, accusing him of "worshipping trees" (adorava as arvores) and refusing to follow the consecrated host in processions. Her perjury had supposedly been motivated by her desire to be rid of her husband and live with her lover. At the time of

\footnotetext{
${ }^{33}$ A.N.T.T., Inquisição de Lisboa, processo $\mathrm{n}^{\circ} 5,037$, fol. $13 \mathrm{v}$.

${ }^{34}$ A.N.T.T., Inquisição de Lisboa, processo $\mathrm{n}^{\circ} 5,037$, fols. $14 \mathrm{r}-14 \mathrm{v}$.

${ }^{35}$ A.N.T.T., Inquisição de Lisboa, processo $\mathrm{n}^{\circ} 5,037$, fols. $14 \mathrm{r}-14 \mathrm{v}$.
} 
this denunciation, Salomão was with the court of Philip III of Spain in the city of Valladolid and got wind of his wife's actions by means that are not recorded in the summary of the interrogation. ${ }^{36}$ Salomão asserted that he had immediately presented himself to the inquisitors in Valladolid to explain the situation to them and counteraccuse his wife both of being a "New Christian" - the descendant of converted Jews and thus an unreliable witness - and of having spoken disrespectfully of the consecrated host. According to Mateus, the inquisitors of Valladolid had dismissed him after admonishing him to lead a "quiet life" with his wife. ${ }^{37}$

\section{- Extradition from Goa to Lisbon}

In the light of the evidence provided by Mateus Salomão, the inquisitors of Goa found themselves in a quandary. His claims regarding previous dealings with the Inquisition in Sicily and Spain needed to be verified, as there were potentially grave ramifications. It was particularly crucial to establish the truth behind the prisoner's confession that he had been falsely arrested in Palermo for possessing a book of necromancy given the evidence received from Leonardo Lobo, specifically his claim that Mateus Salomão possessed a book on herbs that had near-magical powers, such as the ability to grant omniscience.

On 24 November 1610 the inquisitors of Goa wrote to the members of the General Council of the Portuguese Inquisition in Lisbon to inform them that they had unanimously decided that the best course of action was to send Mateus Salomão and the papers of his trial to Portugal so that it could be pursued further by one of the three tribunals operating in Portugal. They argued that the geographical distances between Europe and India, and the length of time that it took ships to sail between the two, would render it impractical for the Goan inquisitors to seek to correspond with colleagues in Spain and Sicily and would extend the proceedings of the trial for many years. Although they did not explicitly mention such a consideration, the inquisitors had probably also taken into account the inescapable fact that such delays would escalate the costs of the trial and place an unwelcome burden upon their already stretched finances. ${ }^{38}$

The response of the General Council to the petition from Goa is not included in the trial dossier but it was positive since Mateus Salomão was indeed sent back to Portugal, doubtless in chains and in the hold, of one of the ships of the Portuguese fleet. A document dating from 20 July 1611 indicates that Mateus Salomão returned to Portugal in the same ship that transported Aleixo de Meneses, the Archbishop of Goa and Portuguese viceroy in India, so that he could take up his new appointments as Archbishop of Braga, primate of Portugal and viceroy of the Habsburg Crown in Portugal. Upon his arrival, Salomão was transferred to the cells of Inquisition's headquarters in Lisbon: the Estaus palace. A certified copy of the documents contained in his trial dossier in Goa also arrived with the same ship. ${ }^{39}$

- Inquiries in Lisbon: Miguel Salomão changes his Story

\footnotetext{
${ }^{36}$ Philip III of Spain moved his court from Madrid to Valladolid between 1601 and 1606.

${ }^{37}$ A.N.T.T., Inquisição de Lisboa, processo $\mathrm{n}^{\circ} 5,037$, fols. $14 \mathrm{v}-15 \mathrm{r}$.

${ }^{38}$ A.N.T.T., Inquisição de Lisboa, processo $\mathrm{n}^{\circ} 5,037$, fol. $15 \mathrm{v}$.

${ }^{39}$ A.N.T.T., Inquisição de Lisboa, processo $\mathrm{n}^{\circ} 5,037$, fols. 6r and $16 \mathrm{r}$.
} 
The tribunal of Lisbon conducted its first interrogation of their new prisoner on 4 November 1611. The inquisitors asked Mateus Salomão a series of detailed questions aimed at establishing a clearer picture of his identity. Mateus identified himself as being aged fifty-one, adding a decade to the age he had previously claimed. Moreover he now revealed that, far from having been born in the port of Laredo in northern Spain, he had been born in a town of "the kingdom of Croatia" whose name was transcribed into Portuguese by the inquisitorial notary as "Ibanys", seemingly a reference to Ivanić-Grad, one of the heavily fortified bastions on the turbulent Austrian-Ottoman frontier. ${ }^{40} \mathrm{He}$ alleged that his parents, however, were from the Basque province of Vizcaya in northern Spain and that he was therefore "a Vizcayan by nation" (biscainho de nação). He declared that he was a soldier in the royal forces. His parents were named Miguel Salomão and Ursula Rijana. They were both deceased and had resided in "Ibanys". Although the inquisitors did not take any note of this, his mother's non-Hispanic surname probably indicates that he was of mixed Spanish-Croatian parentage. He had two brothers and three sisters. His three sisters lived in Asturias (northern Spain) but his two brothers were both soldiers in "Ibanys" and "serving in the estates of Archduke Ferdinand", another reference to the lands of the Austrian Habsburgs in central Europe. ${ }^{41}$

Mateus Salomão's sudden change of age and birthplace were not the only detail of his life that he altered. When asked to provide an account of his life, Mateus Salomão offered the inquisitors a description of an extraordinarily mobile life and proceeded to contradict many of the previous claims that he had made in Goa. Salomão claimed that he was baptised in "Ibaniche" (Ivanić-Grad) by a priest named Padre Vicente and received his confirmation in Vienna (Austria). He stated that, as a teenager aged fourteen or fifteen, he had travelled to Central Europe - which Salomão generically described as "Hungary" - where he had resided for approximately three years. According to the transcript of the interrogation, Salomão apparently travelled in lands under Protestant rule since he witnessed at first hand the effects of the Reformation and claimed to have once been detained by "Lutherans" for attending Catholic services. For a long period he stayed in Vienna, "where they are all Catholics", in the house of an uncle who was employed as a secretary of the Habsburg Emperor. In a confusing section of the transcript of his testimony, Salomão stated that he returned to Spain at the age of eighteen and briefly settled in Madrid where he married Luisa del Aguia but did not have any children, again contradicting his earlier claim in Goa of having two. He eventually ended up in the Italian port of Genoa, where he lived for three years, and then moved to Naples, where he claimed to have served as a soldier and to have been arrested on false charges but then released without charges by the inquisitorial tribunal of Palermo. Following his release, Salomão sailed from Naples to Lisbon when Cardinal Archduke Albert of Austria was appointed to be Philip II of Spain's viceroy in Portugal in 1583 and in due course returned to Spain and established himself in Madrid. ${ }^{42}$ The arrival of Salomão in Madrid coincided with the presence there of the Persian ambassador and it was as a

\footnotetext{
${ }^{40}$ Ivanić-Grad is presently in Croatia.

${ }^{41}$ The reference is to the Habsburg Archduke Ferdinand (1578-1637) who ruled as Archduke of Inner Austria (including Croatia) between 1590 and 1637 and later became the Holy Roman Emperor Ferdinand II between 1619 and 1637.

${ }^{42}$ Cardinal Archduke Albert of Austria (1559-1621) was viceroy of Portugal on behalf of Philip II of Spain between 1583 and 1593.
} 
member of the ambassador's escort that Salomão sailed to the East Indies and eventually ended up in Goa. ${ }^{43}$

Crucially, amid this blizzard of personal biographical information, the prisoner provided more details of his previous dealings with the Inquisition in Sicily and Spain that differed from those he had already made in Goa. The Lisboan inquisitors were particularly interested in what the prisoner had to declare about his previous arrest in Sicily. Salomão replied that he had spent two months and three days in the cells of the Palermitan tribunal "because it was claimed that he had a book of necromancy which was in fact a book of navigation". In Lisbon, however, Salomão now claimed that far from being exonerated from the charges against him, he had been found guilty and sentenced to serve five years in the galleys. He concluded by admitting that he had escaped after serving one year in the galleys and made his way to Madrid.

The indictment drawn up by the inquisitorial prosecutor contained six charges against Salomão, these charges only concerned the accusations of heretical propositions sympathetic with Protestant positions, including slandering and questioning the authority of the Papacy and Inquisition, praising Luther, blasphemously alleging that statues of Jesus, Mary and saints were idols. The prosecutor argued that the charges were grave enough to warrant the handing over of Salomão to the secular authorities for execution. Salomão vehemently denied all of the charges and, on 8 February 1613, he presented his defence, which focused on proving that he was a sincere Catholic. To support his defence, Salomão claimed that he had refused to serve in the army of the dubiously-Catholic King Henry IV of France and named a dozen witnesses who could vouchsafe for his religious sincerity, including the archbishop of Braga-cum-viceroy of Portugal, Aleixo de Meneses, as well as various residents of Madrid. ${ }^{44}$ In addition, Salomão also named four individuals whom he believed may have maliciously accused him although, crucially, he failed to name Leonardo Lobo, his actual accuser in Goa. ${ }^{45}$

\section{- Revelations from Sicily}

This first interrogation, and the sudden volte-face in Mateus Salamão's account of his dealings with the Sicilian Inquisition, raised more questions than answers. To cast some light onto the matter, the inquisitors sent a letter to their colleagues in Palermo soon after the arrival of the prisoner in Lisbon, asking them to forward a copy of any documents that they possessed in their archives pertaining to proceedings against a native of the region of Biscaya in northern Spain named Mateus Salamão. Unfortunately, the response that they received in November 1611 was disappointing as their Palermitan colleagues wrote back asserting that they were unable to unearth any document referring to such an individual despite a search of the registers preserved in their secret archives covering the previous ten years (1611 1601). ${ }^{46}$ Without information from Palermo, the trial of Mateus Salomão had effectively reached an impasse. Nearly a year passed before the frustrated Lisboan

\footnotetext{
${ }^{43}$ A.N.T.T., Inquisição de Lisboa, processo $\mathrm{n}^{\circ} 5,037$, fols. $45 \mathrm{r}-47 \mathrm{v}$

${ }^{44}$ A.N.T.T., Inquisição de Lisboa, processo $\mathrm{n}^{\circ} 5,037$, fols. $52 \mathrm{r}-58 \mathrm{v}$.

${ }^{45}$ Dom Aleixo de Meneses (1559-1617), before his promotion to the archbishopric of Braga, was the Archbishop of Goa between 1595 and 1612 and viceroy of the colony between 1607 and 1609 . A.N.T.T., Inquisição de Lisboa, processo $\mathrm{n}^{\circ} 5,037$, fols. 73r-74v.

${ }^{46}$ A.N.T.T., Inquisição de Lisboa, processo $\mathrm{n}^{\circ} 5,037$, fols. 3r-3v.
} 
inquisitors doggedly sent a second letter to their Sicilian counterparts in October 1612. They believed that linguistic barriers might have confused the inquisitors of Palermo and the second letter was written in Latin. ${ }^{47}$

The breakthrough that the Portuguese inquisitors needed finally arrived in late February 1613 in the form of a parcel from Sicily containing a letter and a document copied from its archives. In their reply, this time also in Latin and dated 7 February, the inquisitors of Palermo informed their Portuguese colleagues that they had finally succeeded in locating the documentary evidence that was sought. The delay had been caused by the fact that the trial of Mateus Salomão in Palermo had not listed his place of origin as either Cantabria or Asturias in northern Spain but rather as "Vienna in [the kingdom of] Hungary". ${ }^{48}$ The information that the inquisitors of Lisbon received from Sicily transformed the direction of the trial of Mateus Salomão by exposing two important lies: one about the nature of his first trial and another about the date when it took place.

The document forwarded with the letter was nothing less than a copy of the first trial of Mateus Salomão in 1606. The date of the trial was significant because the prisoner's claim to have left Italy in the 1580s was thus exposed as a patent lie, possibly made in order to throw the inquisitors off the scent. Moreover, it revealed that Mateus had been arrested in Sicily for uttering heretical propositions and also for "practising the accursed and reproachable art of necromancy, invoking demons (...) in order to find buried treasures and for other purposes". The heretical propositions were particularly serious ones: including attacks on the necessity of the sacrament of Baptism and espousing the heretical doctrine of universal salvation for Jews, Muslims and Christians. He was also accused of denying the miracle of the transfiguration of the Lord and the sacrament of the eucharist. The accusation of necromancy involved claims that he had uttered incantations pleading for demonic intercession and assistance to uncover hidden treasures as well as to communicate with witches. Finally, he had been charged with possessing prohibited books that he used in his practice of necromancy. The indictment of the inquisitorial prosecutor had asked that Mateus be relaxed to the secular arm. ${ }^{49}$

The summary of the trial sent from Palermo to Lisbon gave only a rough outline of the first trial of Mateus and the details of his defence are not included. What is clear is that his defence was only partly successful and the inquisitors were not entirely convinced by his claims. Whilst he did escape a death sentence, the inquisitors of Palermo had condemned him to abjure his errors in a public auto-de-fé and serve five years in the galleys as a "wageless soldier". He had been publically reconciled on 21 September $1606 .^{50}$ With his lies about his past thus exposed, the second trial of Mateus Salomão in Lisbon could proceed in earnest.

- The Defence and Condemnation of Mateus Salamão

The inquisitors of Lisbon sought to verify the other claims made by the defendant. They wrote to their colleagues in the tribunal of Coimbra in northern

\footnotetext{
${ }^{47}$ A.N.T.T., Inquisição de Lisboa, processo $\mathrm{n}^{\circ}$ 5,037, fols. 3r-3v.

${ }^{48}$ A.N.T.T., Inquisição de Lisboa, processo $\mathrm{n}^{\circ}$ 5,037, fol. 36r.

${ }^{49}$ A.N.T.T., Inquisição de Lisboa, processo $\mathrm{n}^{\circ}$ 5,037, fols. 37r-41r.

${ }^{50}$ A.N.T.T., Inquisição de Lisboa, processo $\mathrm{n}^{\circ}$ 5,037, fols. 37r-41r.
} 
Portugal to ask them to question the archbishop of Braga and also to the tribunal of Toledo, in whose district Madrid was located. The Coimbran inquisitors were not able to help them as the archbishop was away at the court in Madrid. The reply from Madrid, dated 18 May 1613, was more encouraging even though they had only been able to locate one of the defence witnesses: Fray Antonio Cano. A long illness had delayed this witness' interrogation by a commissioner of the Toledo Inquisition but the transcript of the interrogation sent to Lisbon helped to support some of the claims made by Mateus.

Fray Antonio Cano confirmed that he knew Mateus Salomão "a foreigner although he does not know of what origin" and "a man most knowledgeable in the use of artillery". He had received his confession and absolved him on an unspecified number of occasions during four or five years. Fray Cano held him to be an excellent Catholic and corroborated his claims that he had refused to serve the King of France despite the attractive salaries offered to specialists like him in France. The witness even recalled the very words expressed by Salomão: "I have been told that the Catholic Faith is not correctly observed in France and that freedom of conscience has been granted so that everyone can live as he wishes. If that is the case then I would not wish to go there even if they offered me the whole kingdom as by the mercy of God I am a Catholic and will die in the Holy [Catholic] Faith". Moreover, Fray Cano maintained that Salomão had once told him: "Father, I value my soul more than anything that is to be found on earth". 51

On 12 July 1613, the inquisitors finally confronted their prisoner with the evidence from Sicily. Summoned from his cell, Salomão was asked to explain why he had lied about his previous dealings with the Inquisition in Sicily. The defendant replied evasively with the improbable claim that he "did not remember that he had abjured [such crimes] in Palermo but that if he did then it must have been so". He still adamantly clung to his position that he had not committed any crimes against the Catholic faith. Such a stubborn stance persuaded the inquisitors to use torture to further their investigation. ${ }^{52}$ On 19 July, Salomão was tortured by being suspended from the ceiling of the torture chamber by his wrists, which were tied behind his back. Although the notary present recorded his desperate shrieks, pleading for the intercession of Jesus and the Virgin Mary, no confession was forthcoming and the hapless Salomão was so weakened that he was unable to sign the transcript of the session. ${ }^{53}$

The failure of torture to extract any new information from Salomão induced the inquisitors to bring the trial to a conclusion. On 23 July, they reviewed the trial and unanimously voted that the defendant could not be found guilty of Protestant heresy based on the evidence of a single witness (Leonardo Lobo). Nevertheless, the lies Salomão had told the inquisitors about his previous imprisonment by the Holy Office in Palermo and his obstruction of the trial convinced the inquisitors that there still remained grave doubts about his sincerity. He was thus sentenced to pay the costs of his trial and to serve a period of imprisonment of a length that was to be determined by the inquisitors. Furthermore, he would appear at a public auto-de-fé held in Lisbon on Sunday 16 February 1614 to hear his sentence as a penitent, holding

\footnotetext{
${ }^{51}$ A.N.T.T., Inquisição de Lisboa, processo $\mathrm{n}^{\circ}$ 5,037, fols. $68 \mathrm{r}-68 \mathrm{v}$.

${ }^{52}$ A.N.T.T., Inquisição de Lisboa, processo $\mathrm{n}^{\circ}$ 5,037, fols. $75 \mathrm{r}-75 \mathrm{v}$ and 77r.

${ }^{53}$ A.N.T.T., Inquisição de Lisboa, processo $\mathrm{n}^{\circ}$ 5,037, fols. 78r-80r.
} 
a candle. Salomão was eventually transferred to the prison for penitent prisoners until he had been properly catechised. The period of imprisonment appears to have been relatively short since a note included in the trial dossier just over a month later indicates that Salomão received a certificate of indoctrination. A statement of the expenses of the trial hastily written on a page at the end of the dossier indicates that it had cost the tribunal of Lisbon a total of 1,940 réis, a not-inconsiderable sum for an institution constantly short of funds. Indeed, the statement reveals that the trial was a financial loss for the Inquisition of Lisbon since Salomão was dispensed from having to pay half of this sum since he was too "poor". 54

\section{Conclusion}

The trial of Mateus Salomão between 1610 and 1614 offers a remarkable insight into the lengths to which the Inquisition would go to overcome vast geographical distances and ensure that a suspected heretic did not avail himself of the opportunities offered by intercontinental mobility to frustrate or even escape inquisitorial justice. During this trial, the inquisitors were faced with three important problems. First of all, the inquisitors needed to establish the true identity of the individual that they had arrested. Secondly, in order to be able to conduct a lawful trial, they had to gather information and transcripts of documents from five tribunals located in different jurisdictions, namely the tribunals of Goa, Lisbon and Coimbra within the Portuguese Inquisition and Toledo (in Castile) and Palermo (in Sicily) within the Spanish Inquisition. Thirdly, they had to ensure that their endeavours to secure the necessary evidence from so many tribunals did not overly extend the duration of the trial and thus increase the cost of Mateus Salamão's imprisonment. They successfully dealt with all these problems and achieved their aim: they obtained the evidence they required and successfully brought the trial to a conclusion.

The actions of the tribunals of the Spanish and Portuguese Inquisitions were certainly hindered by poor communications, the rigidity of administrative rules governing communication between Spanish and Portuguese inquisitorial tribunals and human inefficiency but it would be wrong to conclude that the Inquisition was defeated by the vastness of the oceans and territories separating the overseas colonies from the Iberian Peninsula. The scrupulous record-keeping of the inquisitors, their extended network of commissioners and their ability to collaborate with counterparts in other continents who shared the same mission allowed them to overcome these obstacles. The existing documentary evidence proves beyond doubt that, whenever they had reasons to do so, the inquisitors systematically contacted their colleagues in other continents to ask for evidence necessary for the conclusion of a trial, exchange lists of fugitives and even request genealogical information for applicants seeking to become inquisitorial familiars. Letters might be lost and documents could arrive years after they had been requested but the efforts of the inquisitors were seldom unrewarded. Furthermore, this ability to store data and communicate it across vast distances appears to have been well known beyond the confines of the inquisitorial palaces and cells. Prisoners like Mateus Salamão do not appear to have attempted to hide their previous convictions from the inquisitors even though they could try to present a distorted picture of their prior offences.

\footnotetext{
${ }^{54}$ A.N.T.T., Inquisição de Lisboa, processo $\mathrm{n}^{\circ}$ 5,037, fols. 81r-86r.
} 
A true 'global history' of the Spanish and Portuguese Inquisitions establishing the nature of the exchanges between tribunals and commissioners in Europe the Americas and India still remains to be written. The practical difficulties faced by modern historians - especially the need to conduct prolonged archival research in different countries - means that only a collaborative effort will permit such a 'global history' to materialize. Moreover, such an endeavour will necessitate a systematic analysis of the correspondence of inquisitorial tribunals as well as a fuller examination and understanding of the activity of inquisitorial commissioners. Yet, in the light of the documentary evidence analysed in this article, there can be no doubt that the belief of the procurador general of the province of La Plata in the early seventeenth century that the Inquisition was the only institution disposing of the means to track down, and prosecute, heretics travelling between continents was certainly not a flight of fancy ${ }^{55}$. No other judicial institution in the early modern Spanish and Portuguese empires - and one could also argue in the wider early modern world - disposed of comparable networks and means allowing it to coordinate its actions on a global scale.

\footnotetext{
${ }^{55}$ See footnote one.
} 